\title{
Substrate interactions on the intestinal mucosa: a concept for the regulation of intestinal digestion
}

By A. M. UGOLEV, A. A. GRUZDKOV, P. DE LAEY*, V. V. EGOROVA, N. N. IEZUitova, G. G. KOLTUSHKINA†, N. M. TIMOFEEVA, E. CH. TUlyaganOVA, V. A. TSVETKOVA, M. Yu. CHERNYAKHOVSKAYA AND G. G. SHCHERBAKOV

Laboratory of Physiology of Nutrition, I. P. Pavlov Institute of Physiology, Academy of Sciences of the USSR, Leningrad, USSR

$$
\text { (Received 1o October 1974-Accepted } 29 \text { November 1974) }
$$

r. The hydrolysis of glycyl-L-leucine, glycyl-L-tyrosine, tributyrin, sucrose, maltose, soluble starch and $\alpha$ - and $\beta$-glycerophosphates by everted segments of rat intestine was estimated separately or in combination.

2. A comparative study showed significant interaction between different substrates which affected their digestion.

3. Two types of interaction were identified: products of hydrolysis ( $x$ ) affected the hydrolysis of homologous substances, e.g. methionine and alanine inhibited glycyl-L-leucine hydrolysis, maltose reduced glucoamylase ( $\alpha$-1,4-glucan glucohydrolase; $E C$ 3.2.r.3) activity (intracatenary interactions); (2) interfered with the hydrolysis of a different group of substances, e.g. tributyrin inhibited dipeptidase (glycyl-L-leucine hydrolase; $E C$ 3.4.3.2) and alkaline phosphatase $\left(E C_{3} \cdot 1 \cdot 3 \cdot 1\right)$, glycyl-L-leucine interfered with the activity of the latter enzyme (intercatenary interactions).

4. Mechanisms of interactions were suggested by the results of a comparison of the extent of inhibition or activation of two enzymes (glycyl-L-leucine hydrolase and alkaline phosphatase) in situ in everted intestinal segments or after solubilization with papain or Triton X-100, and different treatments known to affect allosteric sites of these enzymes.

5. Tributyrin and dipeptides were found to act on alkaline phosphatase as allosteric regulators. A discontinuity of the Arrhenius plot suggested the existence of different enzyme conformations which were re-arranged by tributyrin.

6. Substrate interactions in digestion were found in adult rat, cat, rabbit and hen. Substantial differences were found between classes (Aves and Mammalia), orders (rodents, lagomorphs and carnivores) and between age-groups within an animal strain (in this instance, for the rat).

7. These interactions are thought to be involved in the co-ordination of digestion with intestinal absorption and to regulate the time and site of subsequent hydrolysis.

Digestion is the net result of simultaneous interactions of a great number of enzymes within a chaotic environment on a variable mixture of substrates called 'food'. The complexity of digestive processes is self-evident and often discourages the most tenacious students of intestinal physiology. It is not surprising that the mechanisms of its regulation are still not fully understood.

A great deal of information concerning digestion is available: we know which enzymes are involved in these processes, where they are and how they act. But almost all available information derives from studies of the action of individual enzymes on a single substrate under pre-selected experimental conditions. Interactions with sub-

* For reprints; present address: R.I.T., Rue de l'Institut 89, B-I 33 o Rixensart, Belgium.

+ Present address: Institute of Biology, Academy of the Latvian SSR, Riga, USSR.

$\ddagger$ Present address: Veterinary Institute, Leningrad, USSR. 
stances which inhibit, activate, displace or potentiate intestinal enzyme activities have received little attention. Yet we also know that the specific activity of an enzyme in intact cells is altered in response to a change in its immediate environment (Holzer \& Duntze, 1971). Rapid inactivation and reactivation of enzymes is believed to play an important part in metabolic regulation within mammalian cells (Schimke \& Doyle, 1970). If substrate interactions are not considered, the summation of enzyme activities associated with individual substrates can hardly be expected to represent the digestive processes.

Previous experiments in our laboratory have shown that the hydrolysis of individual substrates (disaccharides, dipeptides, triglycerides and glycerophosphates) by everted intestinal segments is frequently altered in the rat by the presence of a second or third substrate (Timofeeva, lezuitova, Chernyakhovskaya, De Laey \& Ugolev, 1967). Most substrates in a bi- or poly-substrate process are hydrolysed by one particular enzyme but often modify the action of others (Ugolev, Iezuitova, Timofeeva, Chernyakhovskaya \& De Laey, 1967). These findings confirm and extend Cori's original discovery (Cori, 1925, 1926) of the existence of an intensive interaction between food substances during their transfer along the intestine.

This study was limited to the influence of various classes of digestible substances on the hydrolysis of glycyl-L-leucine, glycyl-L-tyrosine, tributyrin, sucrose, maltose, starch, $\alpha$ - and $\beta$-glycerophosphate by everted intestinal segments collected from various animal species, and by solubilized intestinal enzymes. These enzymes were also given different treatments known to affect the allosteric sites (heat denaturations and incubations with urea or sulphydryl reagents). A comparison of these reaction rates and their changes in the presence of other substrates propounds some aspects of the mechanisms of the interactions. The physiological significance of these interactions is discussed.

\section{METHODS}

\section{Animals}

Unfasted albino Wistar rats, mean body-weight $200 \mathrm{~g}$, were used routinely. Suckling Wistar rats (10-12 d old), adult Chinchilla rabbits, domestic cats and Russian White hens were also used where indicated.

\section{Tissue preparations}

The animals were killed by cervical dislocation; the small intestine, distal to the ligament of Treitz, was rapidly removed from the body at death, washed in cold Ringer solution, $\mathrm{pH}_{7 \cdot 4}$, freed from mesentery and cut into sections, each of $30-50 \mathrm{~mm}$. Intestinal segments from three to six animals were suspended together in ice-cold Ringer phosphate buffer. By this treatment, each sample would contain random enzyme activities originating from the various segments along the entire length of the small intestine. 


\section{Preparation of soluble enzymes}

In some experiments mucosal scrapings were homogenized and the active forms of the enzymes released into solution by the action of papain in the presence of cysteine (Auricchio, Dahlqvist \& Semenza, I963) or by trypsinization in the presence of Triton X-100 (Eggermont, I968). Papain and Triton X-roo (Schuchardt, Munich, West Germany) were added to the homogenates and shaken for $30 \mathrm{~min}$ at $20^{\circ}$. The particulate residue was removed by centrifugation at $97000 \mathrm{~g}$ for $6 \mathrm{~h}$ using a preparative high-speed centrifuge. In these experiments the supernatant fraction was shown to contain $80-90 \%$ of the original activity of carbohydrases ( $\beta$-fructofuranosidase $\left(E C_{3.2 .1 .26)}, \alpha\right.$-glucosidase $(E C 3.2 .1 .20)$ and glucoamylase $(\alpha$-1,4-glucan glucohydrolase; $E C$ 3.2. . .3) and dipeptides (glycyl-L-leucine hydrolase $(E C$ 3.4.3.2) and glycyl-L-tyrosine hydrolase) but only approximately $40 \%$ of the original activity of alkaline phosphatase $\left(E C_{3} \cdot I_{3} \cdot \mathrm{I}\right)$ from the intestinal mucosa. The method was modified for glucoamylase: crystalline trypsin was added to the homogenate to a final concentration of $\mathrm{I} \mathrm{mg} / \mathrm{ml}$. The mixture was then incubated for $\mathrm{I} h$ at $37^{\circ}$ with constant shaking, cooled, and centrifuged as described for the other enzymes. The supernatant fraction contained at least $80 \%$ of the original activity of glucoamylase. Soluble glucoamylase was partially purified by sedimentation in ethanol followed by adsorption chromatography using DEAE-cellulose as described by Dahlqvist \& Thomson (1963).

\section{Substrates}

A clear distinction was made between two classes of compounds: substances whose hydrolysis was studied (substrates); substances whose influence on an enzymic reaction was studied (modifiers or effectors). Ringer solutions containing (g/l): 3 glycyl-L-leucine or glycyl-L-tyrosine, or 20 sucrose, maltose or soluble starch, or 5 sodium $\beta$-glycerophosphate, or 2.5 tributyrin emulsified with $0.2 \mathrm{Na}$ desoxycholate, were used as substrates. These substances, or equivalent mixtures of products of their hydrolysis (e.g. constitutive amino acids, butyric acid, mono- or dibutyrin) or $2 \cdot 6$ and $5 \mathrm{~g}$ lecithin/l (as an emulsion) were used as modifiers.

\section{Incubations}

Portions of intestinal slices weighing $700 \mathrm{mg}$ were incubated in $16 \mathrm{ml}$ substrate solutions at $\mathrm{pH} 7.4$ and gassed with $\mathrm{O}_{2}-\mathrm{CO}_{2}(95: 5, \mathrm{v} / \mathrm{v})$. The incubation period was $45 \mathrm{~min}$, at either 22 or $37^{\circ}$, with constant shaking (amplitude $10 \mathrm{~mm}$, speed $60 \mathrm{rev} . / \mathrm{min})$. The first sample was withdrawn after incubation for $5 \mathrm{~min}$, subsequent samples were taken at Io min intervals. Tissue homogenates were incubated for ro- $15 \mathrm{~min}$ at $37^{\circ}$ with $16 \mathrm{ml}$ substrate solution. Results for determinations of both enzyme activity and the extent of inhibition or activation by substrates and modifiers were obtained for at least six experiments.

Kinetic constants (Michaelis constant $\left(K_{m}\right)$ and maximum velocity $\left(V_{\max }\right)$ ) of enzymes were determined for different concentrations of substrates or modifiers, or both. 


\section{Enzyme desensitization}

Changes of the conformation or re-arrangement of enzyme sub-units affect the regulatory properties of an enzyme without necessarily affecting its catalytic action. Enzyme desensitization was induced by a mild denaturation of the enzymes by heat treatment (which affects protein conformation), urea treatment (breaking of hydrogen bonds) or by incubation with a sulphydryl reagent. Solutions or suspensions containing the enzymes were heated in some experiments at $56^{\circ}$ for $30-60 \mathrm{~min}$ before their addition to solutions of substrates, or treated with between 2 and $8 \mathrm{M}-\mathrm{urea}$, or treated with a solution of $\mathrm{I} \mathrm{g} \mathrm{Na} p$-chloromercuribenzoate/l.

\section{Estimation of enzyme activity}

The rate of substrate hydrolysis was estimated from the accumulation of the respective products of hydrolysis: quantitative estimations of amino acid concentrations were done using the method of Moore \& Stein (1948) or that of Ugolev \& Timofeeva (1969); for hexoses a modification of the Nelson reaction (Ugolev \& Iezuitova, 1969) was used; glucose concentration was estimated using glucose oxidase (Ugolev \& Iezuitova, I969); glycerol content was determined using a modification of the method of Ugolev \& Chernyakhovskaya (1969); inorganic phosphate content was determined by the method of Fiske \& Subbarow (1925).

\section{RESULTS}

\section{Interactions of substrates on enzyme activity for small intestine slices}

The extent of the modification of the rate of intestinal digestion of various substrates: dipeptides, di- and polysaccharides, triglycerides and phosphate esters, in the presence of different modifiers is shown in Table $\mathbf{I}$.

Dipeptidases. The hydrolysis of solutions containing $3 \mathrm{~g}$ glycyl-L-leucine/l by intestinal slices was significantly reduced after incubation for $45 \mathrm{~min}$ with an emulsion of $2.5 \mathrm{~g}$ tributyrin and dibutyrin/l. Monobutyrin and butyric acid failed to show any significant inhibition of this system. Lecithin significantly reduced glycyl-L-leucine hydrolase activity; in the presence of olive oil the activity of the enzyme was increased, but this was not significant (Table I).

When glycyl-L-leucine was incubated for $45 \mathrm{~min}$ in the presence of another dipeptide ( $3 \mathrm{~g}$ DL- $\alpha$-alanyl-DL-methionine/1), its hydrolysis was not reduced to the same extent as in the presence of an equivalent mixture of alanine and methionine. Starch inhibited the enzyme but sucrose had little or no effect. A mixture of modifiers responded differently: tributyrin inhibition of glycyl-L-leucine hydrolase activity was not significantly affected in the presence of sucrose but was reduced in the presence of olive oil (Table I).

The rate of hydrolysis of glycyl-L-leucine by intestinal slices was reduced to half its original value within $5 \mathrm{~min}$ of incubation in the presence of tributyrin. This rapid inhibition was sustained during the whole incubation period (Fig. I A). It is unlikely that this inhibition was the result of the presence of products of the hydrolysis of 


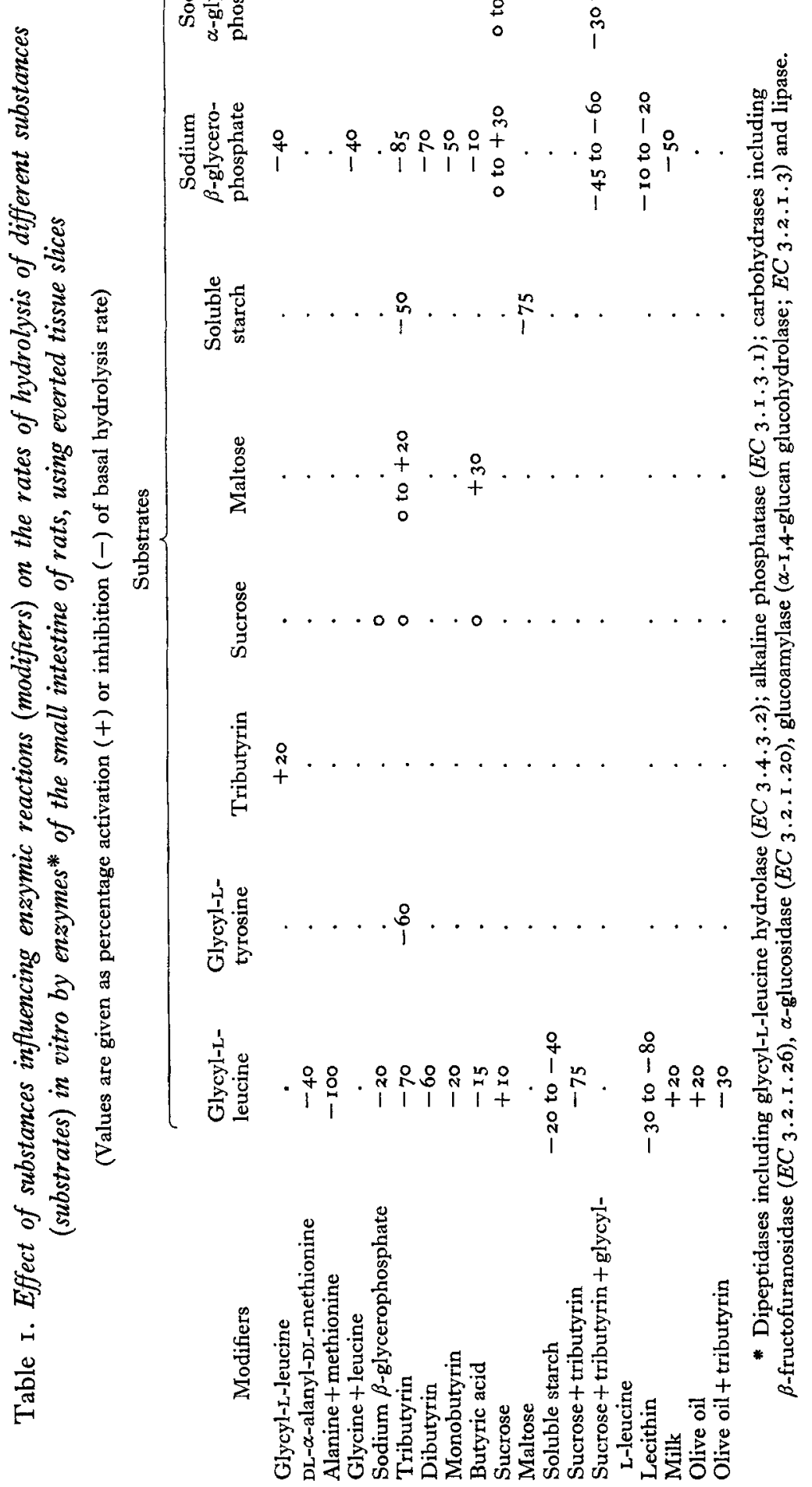




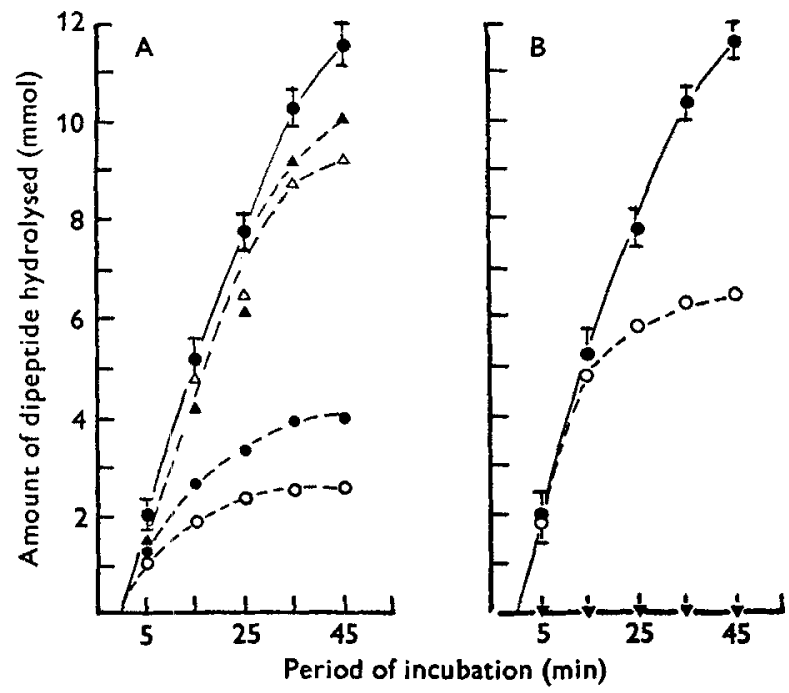

Fig. I. Effect of various modifiers (substances influencing enzyme reactions) on the activity of glycyl-L-leucine hydrolase $(E C 3 \cdot 4 \cdot 3 \cdot 2)$ for everted slices of small intestine from rats, estimated from the accumulation of hydrolysis products. (A) Dipeptidase activity in the absence of a modifier $(-)$; enzymic activity in the presence of the following emulsions, each containing $2.5 \mathrm{~g} / \mathrm{l}$ : tributyrin $(0--0)$, dibutyrin $(--)$, monobutyrin $(\Delta--\Delta)$, butyric acid $(\Delta-\Delta)$. (B) Dipeptidase activity in the absence of a modifier (-); enzymic activity in the presence of $3 \mathrm{~g} \mathrm{DL}-\alpha$-alanyl-DL-methionine/I $(\mathrm{O}-\cdots)$ or an equimolar mixture of alanine and methionine $(\boldsymbol{\nabla}-\nabla)$. Mean values for six experiments. The standard errors, represented by vertical bars, are given for incubations done in the absence of modifiers; those for incubations in the presence of modifiers were similar. For details of procedures, see 'Methods'.

tributyrin which accumulated during incubation with the intestinal tissue slices. Indeed, tributyrin was a more powerful inhibitor of the dipeptidase than dibutyrin; monobutyrin and butyric acid failed to show any significant inhibition of the system. A similar result was also found for the rate of hydrolysis of glycyl-L-tyrosine (Table I). The inhibition of glycyl--L-leucine hydrolase by tributyrin was greatly affected by $\mathrm{pH}$. The highest extent of inhibition was found at the lowest $\mathrm{pH}$ tested (4.5), and this effect decreased with increasing $\mathrm{pH}$. Above $\mathrm{pH} 8.5$ the rate of reaction was significantly enhanced in the presence of tributyrin.

Interactions between dipeptides were of a different kind. DL- $\alpha$-alanyl-DL-methionine inhibition of glycyl-L-leucine hydrolase was low initially and became significant (20\% inhibition) after incubation for $25 \mathrm{~min}$. An equivalent mixture of its constitutive amino acids (alanine and methionine) inhibited glycyl-L-leucine hydrolysis immediately and completely (Fig. I B).

Alkaline phosphatase. Tributyrin emulsions strongly inhibited the rate of hydrolysis of $\beta$-glycerophosphate during the initial stages of incubation (Fig. 2A). The intermediary and final products of hydrolysis of tributyrin when added to the system were less potent than tributyrin itself and followed the inhibitory sequence: tributyrin $>$ dibutyrin $>$ monobutyrin $>$ butyric acid. Both glycyl-L-leucine and an equivalent mixture of its constituent amino acids inhibited alkaline phosphatase, reducing the activity to $40 \%$ of its original value (Fig. $2 \mathrm{~B}$ ). Sucrose did not influence the rate of 


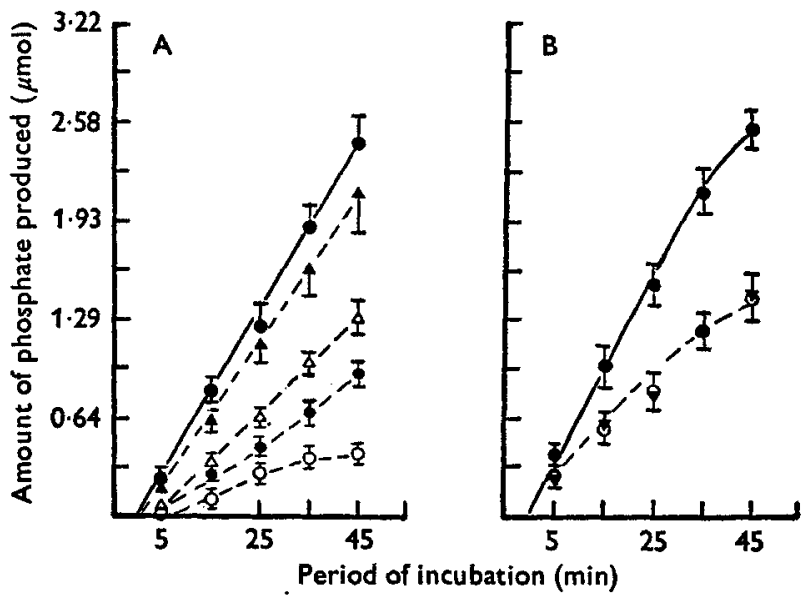

Fig. 2. Effect of various modifiers (substances influencing enzyme reactions) on the activity of alkaline phosphatase $(E C 3.1 .3 .1$ ) for everted slices of small intestine from rats, estimated from the accumulation of hydrolysis products. (A) Alkaline phosphatase activity in the absence of a modifier (-); enzyme activity in the presence of the following emulsions, each containing $2 \cdot 5 \mathrm{~g} / \mathrm{l}$ : tributyrin $\left(\mathrm{O}_{-}-\mathrm{O}\right)$, dibutyrin $\left(\mathrm{O}_{-}-\mathrm{O}\right)$, monobutyrin $(\triangle--\Delta)$, butyric acid $(\mathbf{A}--\mathbf{A})$. (B) Alkaline phosphatase activity in the absence of modifier (-O); inhibition of enzymic activity in the presence of $3 \mathrm{~g}$ glycyl-L-leucine/l $(\mathrm{O}--\mathrm{O})$ or an equimolar mixture of glycine and leucine $(\nabla--\nabla)$. Mean values with their standard errors, represented by vertical bars, for six experiments. For details of procedures, see 'Methods'.

hydrolysis of $\beta$-glycerophosphate (Table I). A mixture of tributyrin, dipeptide and sucrose inhibited alkaline phosphatase but to a lesser extent than tributyrin alone (Table I). An emulsion of tributyrin ( $\left.0_{4} \mathrm{~g} / 1\right)$ significantly increased the $K_{m}$ value for rat intestinal alkaline phosphatase, from 15 to $50 \mathrm{~mm}$, without affecting its $V_{\max }$. This could indicate a competitive inhibition.

Glycyl-L-leucine at concentrations of ${ }_{\mathrm{I}} \cdot 5$ and $3.0 \mathrm{~g} / \mathrm{l}$ reduced the original $V_{\max }$ of this enzyme from 0.29 to $0.12 \mathrm{~mm} / \mathrm{min}$ without affecting the $K_{m}$. This type of effect suggested non-competitive inhibition of the enzyme. When the rate of reaction was estimated using a series of concentrations of modifier at three different substrate concentrations $(2 \cdot 5,5.0$ and $7.5 \mathrm{~g} \beta$-glycerophosphate/1), the point of intersection of the three reciprocal lines gave a value for the inhibitor constant $\left(-K_{i}\right)$ of $2.8 \mathrm{~mm}$ for tributyrin and $5.3 \mathrm{mM}$ for glycyl-L-leucine.

The influence of temperature (the range studied was $0-5^{\circ}$ ) on the hydrolysis of $\beta$-glycerophosphate by alkaline phosphatase from rat small intestinal mucosa revealed a discontinuity in the Arrhenius plot, with higher activation energies at higher temperatures. The energy of activation between 310 and $330^{\circ} \mathrm{K}$ was $21 \mathrm{~kJ} / \mathrm{mol}$; above $330^{\circ} \mathrm{K}$ it was $59 \mathrm{~kJ} / \mathrm{mol}$. This discontinuity was not found in the presence of the modifier tributyrin; the energy of activation was maintained at $46 \mathrm{~kJ} / \mathrm{mol}$ over a temperature range between 310 and $355^{\circ} \mathrm{K}$.

Carbohydrases. Tributyrin, at a concentration which significantly inhibited glycylL-leucine hydrolase and alkaline phosphatase activity for the rat small intestine slices, had no effect on the hydrolysis of sucrose (Fig. ${ }_{3} \mathrm{~A}$ ). The activity of $\beta$-fructofuranosidase in small intestine slices remained unchanged in the presence of glycyl-L-leucine 
A
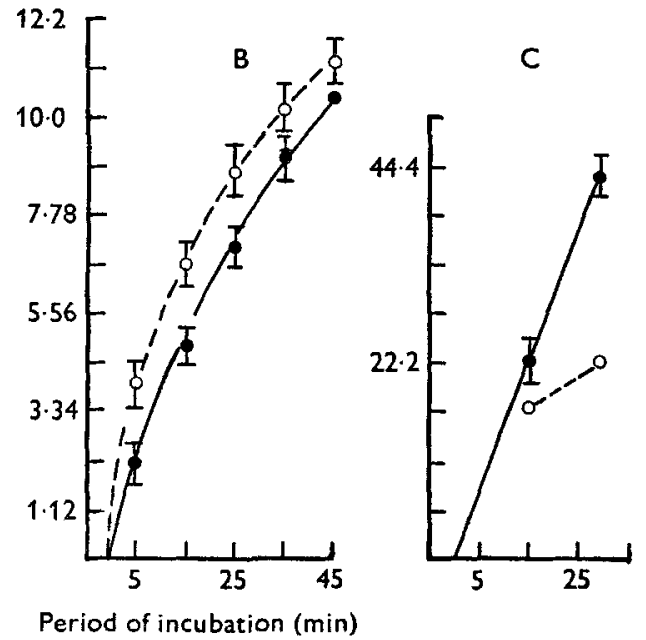

Fig. 3. Effect of tributyrin on the activities of (A) $\beta$-fructofuranosidase $\left(E C C_{3} .2 .1 .26\right)$, (B) $\alpha$-glucosidase $\left(E C C_{3} \cdot 2, \mathrm{I}, 20\right)$, (C) glucoamylase $(\alpha-1,4$-glucan glucohydrolase; $E C$ 3.2.1.3) for either everted slices of rat small intestine, $(\mathrm{A}, \mathrm{B})$ or homogenates of mucosal scrapings from the small intestine of rats (C). - - Enzymic activity in the absence of tributyrin; $\mathrm{O}--\mathrm{O}$, enzymic activity in the presence of an emulsion containing $2.5 \mathrm{~g}$ tributyrin/l. Mean values with their standard errors, represented by vertical bars, for at least six experiments. For details of procedures, see 'Methods'.

and $\beta$-glycerophosphate (Table I). Tributyrin activated $\alpha$-glucosidase for a short time (Fig. $3 B$ ). Butyric acid also stimulated $\alpha$-glucosidase but for a longer period than tributyrin. In contrast, tributyrin showed a definite and sustained inhibition of glucoamylase in homogenates of small intestinal mucosa (Fig. $3 \mathrm{C}$ ).

Lipase. Lipid hydrolysis was studied only in the presence of glycyl-L-leucine. A marginal activation of the hydrolysis of tributyrin was found (Table $\mathrm{I}$ ).

\section{Interactions of substrates on solubilized enzymes}

Tributyrin and its hydrolysis products retained their inhibitory properties for glycyl-L-leucine hydrolase and alkaline phosphatase after solubilization of both enzymes (Fig. 4 A, B). Certain differences in the kinetics of inhibition were found between the two forms of the enzymes, bound or soluble. Within the tissue, alkaline phosphatase was rapidly inhibited by tributyrin but its effect was reduced as incubation continued (Fig. 2A). The inhibition of solubilized alkaline phosphatase was less pronounced initially but increased as incubation proceeded (Fig. ${ }_{4} \mathrm{~B}$ ). On the other hand, the effect of tributyrin on glycyl-L-leucine hydrolase activity was not dependent on the form of the enzyme. It was essentially the same for the solubilized enzyme (Fig. 4A) and for the enzyme bound as part of an intact intestinal membrane (Fig. I A).

\section{Interactions of substrates on desensitized enzymes}

Partially denaturated alkaline phosphatase was less sensitive than the untreated enzyme to tributyrin, glycyl-L-leucine or an equivalent mixture of glycine and leucine. The extent of inhibitions by all modifiers was reduced after heating the enzyme at $5^{\circ}$ for 30,45 and 60 min (Fig. $5 \mathrm{~A}$ ). 


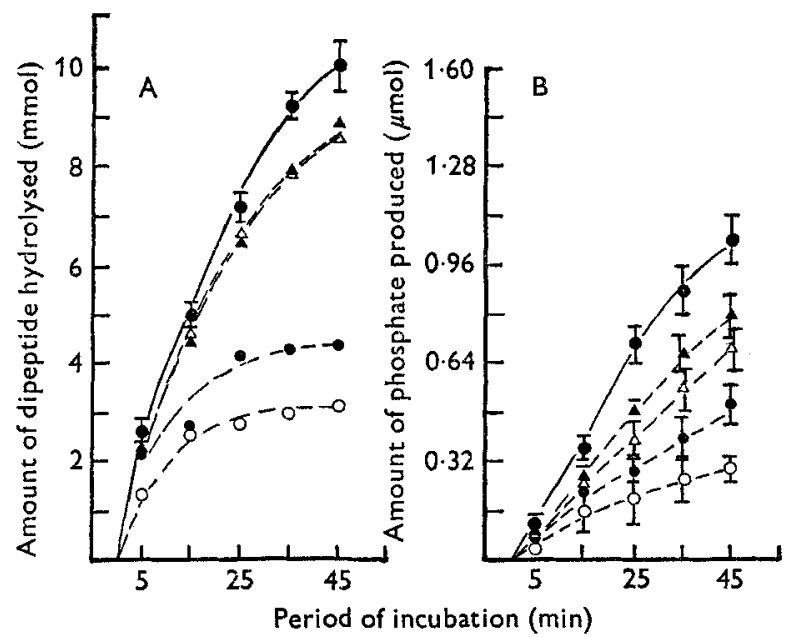

Fig. 4. Effect of tributyrin and the products of its hydrolysis on the activity of solubilized enzymes: (A) glycyl-L-leucine hydrolase $(E C$ 3.4.3.2) and (B) alkaline phosphatase $\left(E C_{3.1 .3 .1)}\right.$ released from scrapings of the small intestinal mucosa of rat by the action of papain in the presence of cysteine. Enzymic activity in the absence of tributyrin; - - enzymic activity in the presence of the following emulsions, each containing $2.5 \mathrm{~g} / 1$ : tributyrin $(\mathrm{O}-\mathrm{O})$, dibutyrin $(\mathbf{-}-\mathbf{0})$, monobutyrin $(\Delta--\Delta)$, butyric acid $(\boldsymbol{\Delta}--\mathbf{\Delta})$. Mean values with their standard errors, represented by vertical bars, for six experiments. For details of procedures, see 'Methods'.

Treatment of alkaline phosphatase with increasing concentrations of urea (between 2 and $8 \mathrm{M}$ solutions) resulted in a linear reduction of the inhibition by tributyrin (Fig. 5B). The same treatment did not affect the inhibitory action of glycyl-Lleucine for alkaline phosphatase (Fig. 5 B).

In the presence of $p$-chloromercuribenzoate $(0 \cdot \mathrm{I} / \mathrm{l})$ the activity of both enzymes was slightly reduced (mean values for glycyl-L-leucine hydrolase and alkaline phosphatase, 65 and $70 \%$ of their original activity respectively), but the inhibition of the dipeptidase by tributyrin was sustained (mean value, $40 \%$ inhibition of activity) and alkaline phosphatase was no longer inhibited by tributyrin (mean value, $-5 \%$ inhibition of activity) (Fig. $5 \mathrm{C}$ ).

\section{Species-dependent interactions}

Dipeptidase activity of the small intestine from hens was significantly reduced in the presence of tributyrin and butyric acid (Fig. 6A), but to a lesser extent than that for the rat (Fig. I A). The difference in dipeptidase sensitivity between the two species was even more pronounced for the solubilized forms of the enzymes; the hen dipeptidase (Fig. 6B) seemed to be more resistant than rat dipeptidase to the two modifiers (Fig. 4A). Differences were also found between different orders of mammals (Fig. 7). Feeding habits, types of food and intestinal enzyme activities are obviously different in rodents, lagomorphs and carnivores. The alkaline phosphatase activities for proximal segments of intestine were significantly higher for rats than for cats and rabbits (Fig. $7 \mathrm{~A}, \mathrm{~B}, \mathrm{C}$ ). However, after $45 \mathrm{~min}$ incubation with tributyrin, the extent of inhibition of the high alkaline phosphatase activity for rat intestine and 
A

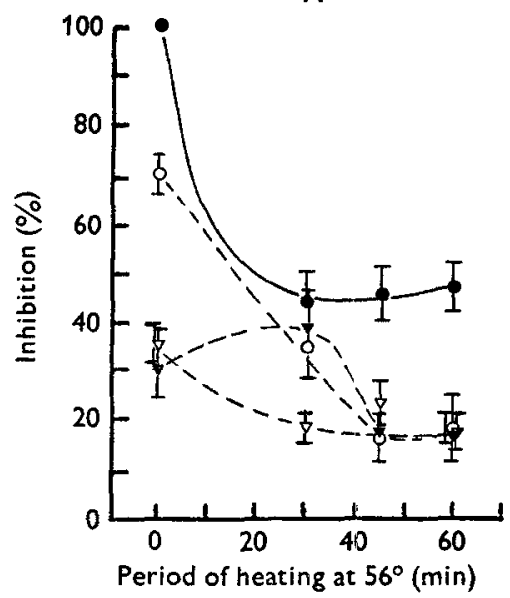

B

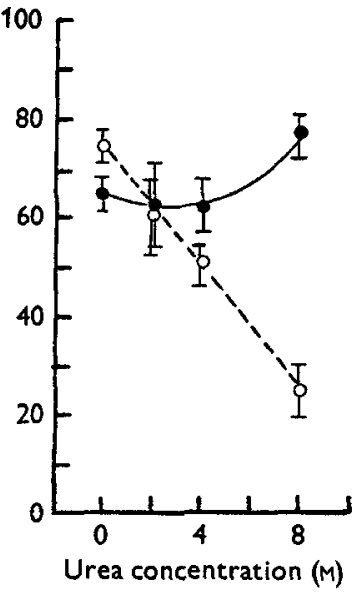

C

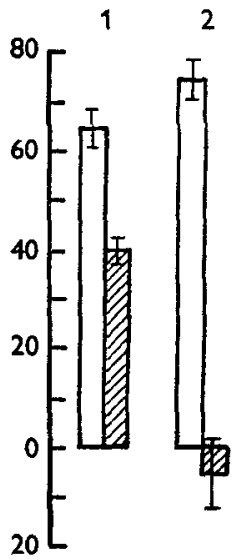

Fig. 5. Effect of tributyrin or glycyl-L-leucine on the activity of enzymes for tissue homogenates of rat small intestinal mucosa, which had been desensitized by heat or urea treatment, or by the presence of a sulphydryl reagent. (A) Heat denaturation by preliminary heating of tissue homogenates at $56^{\circ}$ : alkaline phosphatase $(E C 3.1 \cdot 3.1)$ activity (\% activity of non-heated homogenate) (-); inhibition (\%) of hydrolysis of sodium $\beta$-glycerophosphate, after $45 \mathrm{~min}$ incubation with: an emulsion containing $2.5 \mathrm{~g}$ tributyrin/l $(O--O)$, a solution containing $3 \mathrm{~g}$ glycyl-L-leucine/1 $(\nabla--\nabla)$, an equimolar mixture of glycine and leucine $(\boldsymbol{\nabla}--\nabla)$. (B) Alkaline phosphatase activity in homogenates treated with different concentrations of urea $(2-8 \mathrm{M})$. Inhibition (\%) of hydrolysis of sodium $\beta$-glycerophosphate after $45 \mathrm{~min}$ of incubation with: $3 \mathrm{~g}$ glycyl-L-leucine/1 (-), an emulsion containing $2.5 \mathrm{~g}$ tributyrin/1 ( $\mathrm{O}--\mathrm{O})$. (C) (1) Glycine-L-leucine hydrolase $(E C 3 \cdot 4 \cdot 3 \cdot 2)$ and (2) alkaline phosphatase activities in the presence of a solution of $\mathrm{Na} p$-chloromercuribenzoate $(\mathrm{r} \cdot \mathrm{\circ g} / 1)$. $\square$, Desensitized enzyme activity (\% original activity); $\square$, inhibition $(\%)$ of desensitized enzymes in the presence of an emulsion containing $2.5 \mathrm{~g}$ tributyrin/l. Mean values with their standard errors, represented by vertical bars, for twelve experiments. For details of experimental procedures, see 'Methods'.

the lower activity for rabbit intestine was the same (Fig. $7 \mathrm{~A}, \mathrm{C}$ ), although the pattern of inhibition in the $45 \mathrm{~min}$ period was different. For the cat, however, alkaline phosphatase was inhibited by tributyrin initially but activity increased rapidly as incubation proceeded (Fig. 7 B). Inhibition of the same enzyme by glycyl-L-leucine was more pronounced for the cat than for the rat or rabbit (Fig. $7 \mathrm{~A}, \mathrm{~B}, \mathrm{C}$ ).

There is evidence that this effect could be age-dependent within the same strain of animals. For adult Wistar rats, alkaline phosphatase inhibition induced by tributyrin and glycyl-L-leucine increased as incubation proceeded, whereas for suckling rats at ro-r $2 \mathrm{~d}$ of age, the extent of the inhibition of the same enzyme was lower and did not change throughout the period of incubation.

\section{DISCUSSION}

Substances which are readily digested and absorbed were found to affect the rate of intestinal hydrolysis of two dipeptides, di- and polysaccharides, triglycerides and glycerophosphates in various ways. The results summarized in Table I suggested a rather unpredictable and inco-ordinate series of interactions; some enzymic activities were apparently inhibited whereas others are unaffected or even activated. However, 


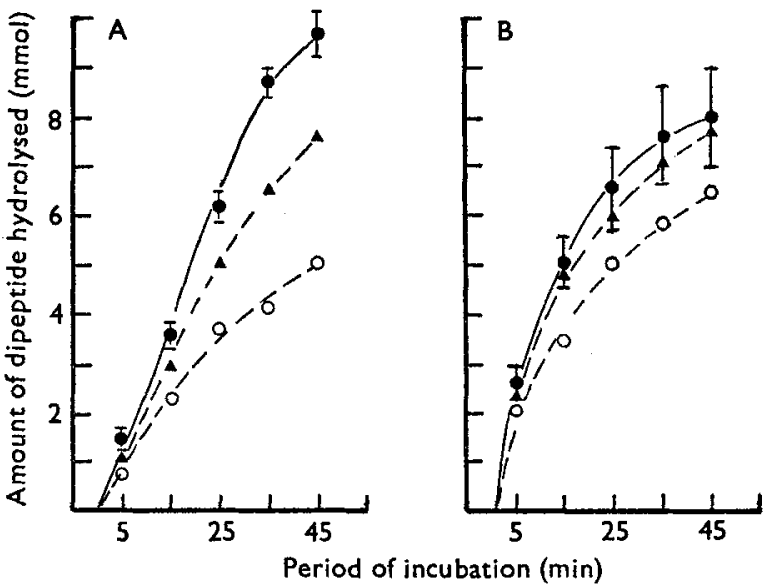

Fig. 6. Effect of modifiers (substances influencing enzyme reactions) on the activity of glycylL-leucine hydrolase $(E C 3.4 .3 .2)$ for the small intestine from hens, which was studied for the membrane-bound enzyme (tissue slices) (A) or for enzyme which had been released from scrapings of the small intestinal mucosa by the action of papain in the presence of cysteine (B). Enzymic activity in the absence of modifier (-) ; enzymic activity in the presence of the following emulsions each containing $2 \cdot 5 \mathrm{~g} / 1$ : tributyrin $(\mathrm{O}--\mathrm{O})$, butyric acid $(\mathbf{\Delta -}-\mathbf{\Delta})$. Mean values with their standard errors, represented by vertical bars, for six experiments. For details of procedures, see 'Methods'.
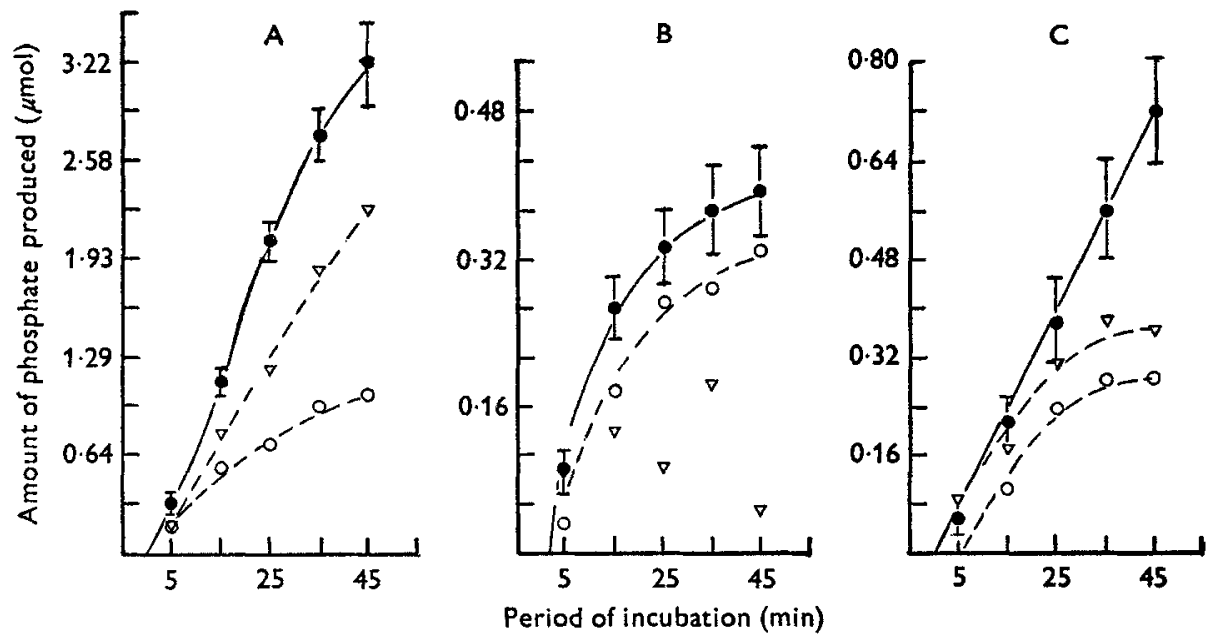

Fig. 7. Effect of various modifiers (substances influencing enzyme reactions) on the activity of alkaline phosphatase $\left(E C_{3.1 .3 .1}\right)$ for proximal segments $(30-50 \mathrm{~mm})$ of the small intestine from (A) rats, (B) cats and (C) rabbits. Enzymic activity in the absence of a modifier ( - ): enzymic activity in the presence of: an emulsion containing $2.5 \mathrm{~g}$ tributyrin $/ 1(\mathrm{O}--\mathrm{O})$; a solution containing $3 \mathrm{~g}$ glycyl-L-leucine $/ \mathrm{l}(\nabla--\nabla)$. Mean values with their standard errors, represented by vertical bars, for six experiments. 
the variable effects of the modifiers provide some information. First, the small intestinal mucosa and its surface can reasonably be considered as the main site of interaction. Indeed, all intestinal enzymes studied in our experiments have been located within the intestinal brush border by many workers (for review, see Ugolev \& De Laey, 1973). Experimental conditions were selected on this basis. Secondly, interactions found resulted mainly in the inhibition of hydrolysis; activation of the system was only found in eight of thirty-four interactions. Thirdly, there was no pattern of interaction between substances of the same or different groups of compounds. If digestion is regarded as a gradual hydrolysis of proteins, fats and carbohydrates, two types of interactions could be expected: a product of one series of hydrolyses may either affect the hydrolysis of homologous substances (intracatenary interactions) or interfere with the hydrolysis of a different group of substances (intercatenary interactions). Our results suggest that both types of interaction can be found at the same time in the same hydrolysis system in the digestion process but the effects of interactions may follow different time courses.

Intercatenary interactions. These depended on the presence of modifiers and were rapid at first, e.g. the action of tributyrin on glycyl-L-leucine hydrolase and alkaline phosphatase. Intestinal hydrolysis of the modifier into an absorbable form substantially reduces its influence: butyric acid and monobutyrin were not as effective inhibitors of these enzymes as an equivalent amount of di- or tributyrin.

Intracatenary interactions. These apparently depended on the action of products of hydrolysis as modifying agents. These interactions were slow at first. For the first 20 min of incubation with DL-alanyl-DL-methionine there was no detectable inhibition of glycyl-L-leucine hydrolase. Inhibition was probably dependent on the rate of hydrolysis of the modifier: an equivalent mixture of alanine and methionine was found to inhibit the reaction at once and completely. The inhibition, therefore, was not the result of dipeptide interaction but was probably the result of a local accumulation of high concentrations of amino acids at the site of hydrolysis.

Enzymic activities could have been altered either by the direct action of the modifier on the enzyme within the membrane or by an action on the membrane which, in turn, affects the enzyme activity. A comparative study of the action of the same modifier on membrane-bound or solubilized enzymes could indicate the site of action. The effect of tributyrin on the activities of two enzymes studied was different. Tributyrin inhibited both bound and solubilized glycyl-L-leucine hydrolase (Fig. $4 \mathrm{~A}$ ): a direct effect on the enzyme is suggested. For alkaline phosphatase, inhibition by tributyrin was lower for the solubilized enzyme (Fig. 4 B): a certain amount of interaction between tributyrin and the membrane cannot, therefore, be excluded.

Direct interaction of substances with an enzyme can be subdivided into isosteric, allosteric or homosteric actions.

The type of interactions could be identified using changes in kinetic characteristics or by affecting the regulatory centre of these enzymes using desensitizing agents. These agents are thought to have a selective effect on the regulatory centre of the enzyme without affecting its catalytic properties (Gerhart \& Pardee, I961, 1962, 1964).

(a) The results of kinetic analysis suggest competitive inhibition of rat intestinal 
alkaline phosphatase by tributyrin and lecithin but non-competitive inhibition by dipeptides. Whether or not the type of inhibition is a reliable index for the classification of the interaction is uncertain (Ghosh \& Fishman, 1968).

(b) As the two forms of inhibition (competitive by tributyrin and non-competitive by dipeptide) are not found with desensitized alkaline phosphatase (Fig. $5 \mathrm{~A}$ ), these two modifiers could probably act as allosteric regulators of enzyme activity. Desensitization using three methods gave three different responses (Fig. $5 \mathrm{~A}, \mathrm{~B}, \mathrm{C}$ ). This may indicate either a certain extent of non-homogeneity within the regulatory centre of the enzyme, or the presence of several regulatory sites within one enzyme protein.

(c) A temperature-dependent discontinuity of the Arrhenius plot suggested that two different conformations of alkaline phosphatase co-exist within the intestinal mucosa. Each conformation is characterized by its energy of activation. Tributyrin probably induced a new conformation in the enzyme which remained stable over the entire range of temperatures between 310 and $355^{\circ} \mathrm{K}$.

The regulation of digestion should probably be attributed to the complex structure of certain key enzymes in the final stages of digestion. Substrate- or modifier-induced conformational changes often involve catalytic and regulatory sub-units of the enzyme protein.

\section{Physiological significance}

Co-ordination of digestion with transport. The functional efficiency of the intestinal tract depends on co-ordination between digestion and absorption. The capacity of the intestine to absorb should equal its total digestive potential, and the rate of intestinal absorption should therefore be comparable with the rate of hydrolysis of most food substances. However, results of perfusion studies using human intestine have indicated that the rate of hydrolysis of dimers or polymers exceeds the rate of monomer transport through the intestinal wall. Gray \& Ingelfinger (1965, I966) reported a higher rate of hydrolysis of sucrose and maltose in comparison with the rate of monosaccharide transport in man. Digestion of starch and triglycerides is faster than absorption of their products of hydrolysis in man (Table 2). Matthews has suggested that the rate of hydrolysis of most dipeptides in rat intestine is significantly higher than the forward transport of liberated amino acids (Cheng \& Matthews, I970; Cheng, Navab, Lis, Miller \& Matthews, I97 I Burston, Addison \& Matthews, 1972) (Table 2). Only four peptides have been found to have a rate of hydrolysis which is slower than the transport of their constituent amino acids. Their structure is rather unusual: they are $\gamma$-peptides or dipeptides containing D-isomers.

The difference found between digestion and absorption in man and rat would suggest that only a fraction of the products of digestion could be reabsorbed at any one time. A functional overloading of the proximal segments would result in saturation of the transport system and a release of unabsorbed monomers within the lumen. The presence of these monomers, which are osmotically active substances, would result in the accumulation of large amounts of fluid in the lumen, and would change the lumen contents into an excellent culture medium for bacterial flora. Fermentations and diarrhoea would be common complaints. However, under normal physiological 


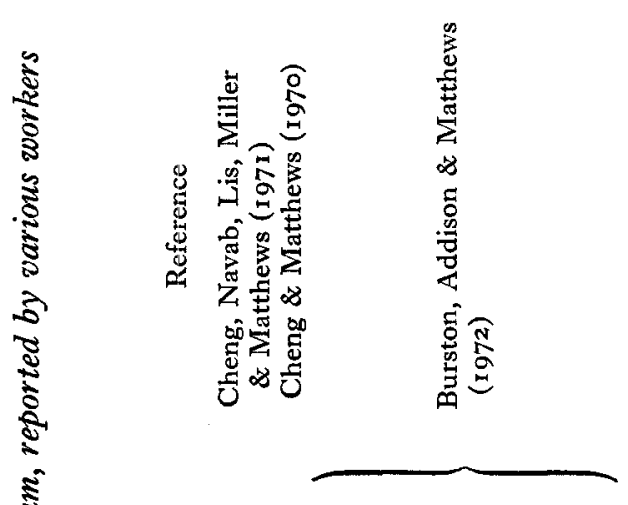

产

芯

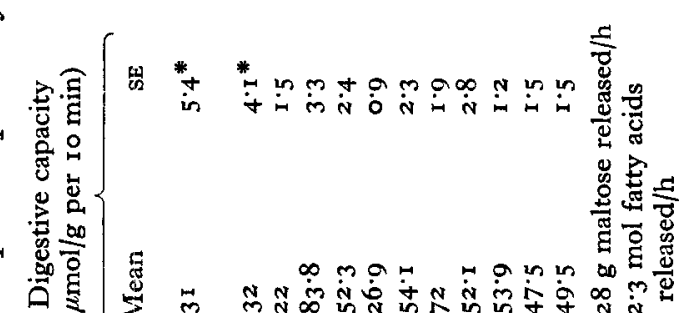

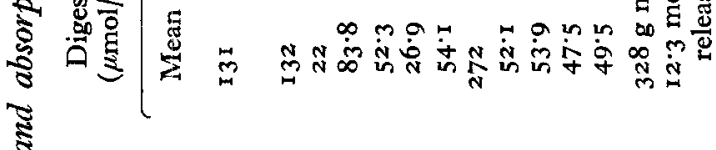

:

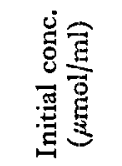

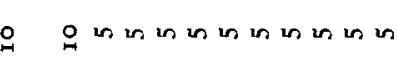

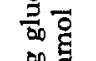

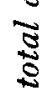

sิ

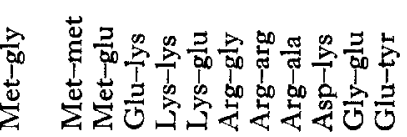

$\frac{\sqrt{5}}{\sqrt{5}}$

3
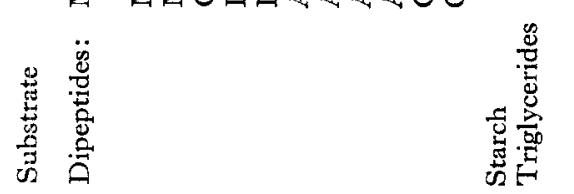

. ํㅐ

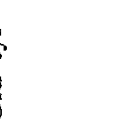

때용

है

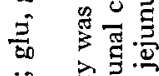

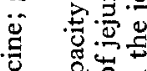

要

की

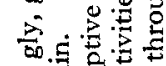

की है

$\dot{\mathrm{i}}$

党

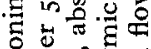

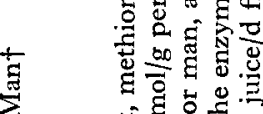


circumstances these complaints are exceptional. It is reasonable to believe that under normal physiological conditions, absorption keeps up with the rate of digestion. The reduction found in hydrolytic activity of the intestine as a result of substrate interactions might perhaps be responsible for a better co-ordination of digestion with absorption. The interactions of food substances during their hydrolysis preclude this functional overload.

Time sequences of digestion. The individual rates of hydrolysis of proteins are considered to be faster than the hydrolysis of carbohydrates and the slowest process involves the digestion of fat, but given as a mixture, first fats are digested, then carbohydrates and finally proteins (Ovdeichuk \& Ugolev, I966; Ugolev, Iezuitova, Timofeeva \& Chernyakhovskaya, 1970; Ugolev, 1972). This succession of processes reflects the sequence of absorption of nutrients in vivo (Borgström, Dahlqvist, Lundh \& Sjövall, 1957).

The alteration of rates of digestion by the interaction of different food substances affects the timing and the location of subsequent digestive processes.

Finally, the results of an exploratory analysis of the effect of substrate interactions on intestinal hydrolysis for the rat and hen, and for three different orders of mammals (rodents, lagomorphs and carnivores) suggested that: ( $\mathrm{I}$ ) substrate interactions are not peculiar to a single class of vertebrates; (2) there are substantial differences between classes (e.g. Aves and Mammalia), orders, and age groups within an animal strain (in this instance, for the rat).

A systematic application of this comparative method to different species and under various experimental conditions could perhaps provide an explanation for the coordination of the complex functions of the intestine to meet the requirements of the whole body.

\section{REFERENCES}

Arnesjö, B., Nilsson, A., Barrowman, J. \& Borgström, B. (1969). Scand. F. Gastroenterol 4, 653 .

Auricchio, S., Dahlquist, A. \& Semenza, G. (1963). Biochim. biophys. Acta 73, 582.

Borgström, B., Dahlqvist, A., Lundh, G. \& Sjövall, J. (1957). F. clin. Invest. 36, I521.

Burston, D., Addison, J. M. \& Matthews, D. M. (1972). Clin. Sci. 43, 823.

Cheng, B. \& Matthews, D. M. (1970). F. Physiol., Lond. 2ro, 37 P.

Cheng, B., Navab, F., Lis, M. 'T., Miller, N. \& Matthews, D. M. (1971). Clin. Sci. 40, 247.

Cori, C. F. (1925). J. biol. Chem. 66, 691.

Cori, C. F. (1926). Proc. Soc. exp. Biol. Med. 24, 125 .

Dahlquist, A. \& Thomson, D. L. (1963). Biochem. F. 89, 272.

Eggermont, F. (1968). The biochemical defects in sucrose intolerance and in glucose-galactose malabsorption. PhD Thesis, Catholic University of Louvain, Louvain.

Fiske, C. H. \& Subbarow, Y. (1925). F. biol. Chem. 66, 375 .

Gerhart, J. C. \& Pardee, A. B. (I96I). Fedn Proc. Fedn Am. Socs exp. Biol. 20, 224 Abstr.

Gerhart, J. C. \& Pardee, A. B. (I962). J. biol. Chem. 237, 89r.

Gerhart, J. C. \& Pardee, A. B. (1964). Fedn Proc. Fedn Am. Socs exp. Biol. 23, 727.

Ghosh, N. K. \& Fishman, W. H. (1968). Archs Biochem. Biophys. 126, 700.

Gray, G. M. \& Ingelfinger, F. J. (1965). F. clin. Invest. 44, 390.

Gray, G. M. \& Ingelfinger, F. J. (1966). F. clin. Invest. 45, 388 .

Holzer, H. \& Duntze, W. (1971). A. Rev. Biochem. 40, 345 .

Moore, S. \& Stein, W. H. (1948). F. biol. Chem. 176, 367 .

Ovdeichuk, R. A. \& Ugolev, A. M. (1966). The Problems of Biochemical Adaptation. Moscow: Izdaniya Nauka.

Schimke, R. T. \& Doyle, D. (r970). A. Rev. Biochem. 39, 929.

Timofeeva, N. M., Tezuitova, N. N., Chernyakhovskaya, M. Yu., De Laey, P. \& Ugolev, A. M. (1967). Dokl. Akad. Nauk SSSR 176, 145 I. 
Ugolev, A. M. (1972). Membrane Digestion. Polysubstrate Processes, Organisation and Regulation. Leningrad: Izdaniya Nauka.

Ugolev, A. M. \& Chernyakhovskaya, M.Yu. (1969). In Studies on Digestive System in Man [A. M. Ugolev, editor]. Leningrad: Izdaniya Nauka.

Ugolev, A. M. \& De Laey, P. (1973). Biochim. biophys. Acta 300, 105.

Ugolev, A. M. \& Iezuitova, N. N. (1969). In Studies on Digestive System in Man [A. M. Ugolev, editor]. Leningrad: Izdaniya Nauka.

Ugolev, A. M., Tezuitova, N. N., Timofeeva, N. M. \& Chernyakhovskaya, M. Yu. (1970). Nahrung r4, 453.

Ugolev, A. M., Tezuitova, N. N., Timofeeva, N. M., Chernyakhovskaya, M. Yu. \& De Laey, P. (1967). Tijdschr. Gastroent. 10, I52.

Ugolev, A. M. \& Timofeeva, N. M. (1969). In Studies on Digestive System in Man [A. M. Ugolev, editor]. Leningrad: Izdaniya Nauka.

Wilson, T. H. (I 962). Intestizal Absorption. Philadelphia and London: W. B. Saunders Co. 